Rev. Mariusz SZRAM ${ }^{*}$

\title{
WHAT BODY WILL NOT INHERIT THE KINGDOM OF GOD? AN EARLY CHRISTIAN EXEGESIS OF THE FIRST EPISTLE TO THE CORINTHIANS 15:50
}

The truth of faith concerning the resurrection of the body, constituting - according to the significance of Saint Paul's First Letter to the Corinthians - the core of Christianity, stands in opposition with a statement appearing several dozen verses later in the same epistle (1Cor 15:50): "flesh and blood cannot

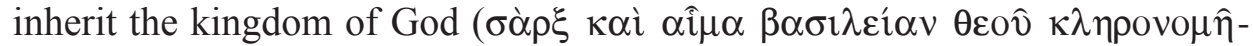
$\sigma \alpha \imath$ ov $\left.\delta v v^{\prime} \alpha \tau \alpha\right)$ )". The above-quoted line was the subject matter of thorough deliberation during the Patristic period. I shall trace its exegesis in early Christian literature, comparing the writings of three authors, representing basic geographical and cultural traditions functioning in the Church during the first centuries $^{1}$. These will be: Irenaeus (died approximately 202 AD) - related to the Asian tradition, preferring the literal biblical exegesis; Tertullian of Carthage (c. 155 - died after 220 AD) - a representative of the North African tradition, parallel in many respects to the Asian practice; and Origen (185 - died approximately $254 \mathrm{AD}$ ) - derived from the Alexandrian tradition preferring primarily the allegorical analysis ${ }^{2}$. Irenaeus and Tertullian have left no separate

\footnotetext{
* Rev. prof. dr hab. Mariusz Szram - Department of Greek and Latin Patrology at the Institute of the History of the Church and Patrology at the Faculty of Theology of John Paul II Catholic University of Lublin, e-mail: m.szram@wp.pl.

${ }^{1}$ The present elaboration is an explication of the theses initially addressed in my monograph: M. Szram, Ciało zmartwychwstałe w myśli patrystycznej przełomu II i III wieku, Lublin 2010, 296297, 317-320, 333-338, 355-358 and 536-547. Thus far, the present subject of research has been touched upon in the article: E. Pietrella, "Caro et sanguis regnum Dei possidere non possunt" (1 Co XV, 50), "Aevum" 49 (1975) 36-76. Its author depicts mainly the gnostic background, whereas the commentary on the early Christian patristic exegesis of 1 Cor does not take into consideration Origen's views.

${ }^{2}$ On the characteristic features of the Asian and Alexandrian traditions see: M. Simonetti, Teologia alessandrina e teologia asiatica al concilio di Nicea, "Augustinianum" 13 (1973) 369-398; idem, Asiatica (cultura), DPAC I 414-416; idem, Modelli culturali nella cristianità orientale del II-III secolo, in: De Tertullien aux Mosarabes. Antiquité tardive et Christianisme ancien (III ${ }^{-}-\mathrm{VI}^{e}$ siècles). Mélanges offerts à Jacques Fontaine, ed. L. Holtz - J.C. Fredouille - M.H. Jullien, vol. 1, Paris 1992, 381-392.
} 
comments on the First Epistle to Corinthians, and no Origen's comment survived to our day only a few fragments ${ }^{3}$ that unfortunately do not concern the interesting sentence. The same applies to the stored in catenas fragments of later comments to the letter by Didymus the Blind, Cyril of Alexandria, Eusebius of Emesa or Theodore of Mopsuestia ${ }^{4}$. Hence, various letters of these authors will provide the source base, according to the principle formulated by Manlio Simonetti, namely that the Fathers of the Church "were always thinking with the Bible"s.

Worth mentioning is the fact that Apostle Paul by the present in our verse term $\sigma \alpha ́ \rho \xi$ comprehended above all such features of corporeal body as: its transience, destructibility and lethality (cf. 1Cor 7:28; 2Cor 4:11); as well as earthly behaviour, bodily acts, life under the rule of lust (cf. 2Cor 1:17; Rom 8:6-7; Gal 5:17) ${ }^{6}$. The early Christian orthodox authors remained to all intents and purposes dedicated to this notion. They also attempted to ascribe to the term in question, $\sigma \alpha \dot{\alpha} \rho \xi$, its literal and physical meaning, related to the material specificity of human body. In doing so, they always attempted to perform that in a diverse manner than using the Pauline verse to wrong ends as did Gnostics, refusing the concept of resurrection of the earthly body?

1. Irenaeus - the Asian tradition. In Adversus haereses, the fifth book of his fundamental work directed against different factions of the second century

\footnotetext{
${ }^{3}$ Cf. Origenes, Fragmenta Commentariorum in 1 Epistulam ad Corinthios, ed. C. Jenkins, JTS 9 (1908) 231-247, 353-372 and 500-514; JTS 10 (1909) 29-51.

${ }^{4}$ Compare the extensive selection of patristic commentaries to Saint Paul's First Letter to Corinthians: J.L. Kovacs, 1 Corinthians Interpreted by Early Christian Commentators, Grand Rapids 2005. Cf. P. Boucaud, Corpus Paulinum. L'exégèse grecque et latine des Épitres au premier millénaire, RHR 230 (2013) fasc. 3, 299-332.

${ }^{5} \mathrm{Cf}$. M. Simonetti, Lettera elo allegoria. Un contributo alla storia dell'esegesi patristica, SEA 23, Roma 1985, 9.

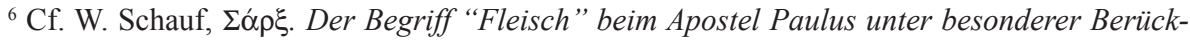
sichtigung seiner Erlösungslehre, Münster 1924, 99-165; J.A.T. Robinson, The Body: A Study in Pauline Theology, London 1952; Listy do Koryntian. Wstęp - Przekład z oryginalu - Komentarz, red. E. Dąbrowski, Poznań 1965, 284; A. Sand, Der Begriff "Fleisch" in den paulinischen Hauptbriefen, Regensburg 1967; C.K. Barrett, A Commentary on the First Epistle to the Corinthians, London 1968, 379; R. Jewett, Paul's Anthropological Terms. A Study of Their Use in Conflict Settings, Leiden 1971, 144-160; The New International Dictionary of New Testament Theology, ed. C. Brown, vol. 1, Exeter - Devon - Grand Rapids - Michigan 1975, 222 and 229; R.H. Gundry, $\Sigma \hat{\omega} \mu \alpha$ in Biblical Theology with Emphasis on Pauline Anthropology, Cambridge 1976; X. LéonDufour, Ciato, in: Stownik teologii biblijnej, ed. idem, translated from French to Polish by K. Ro-

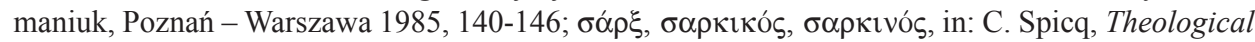
Lexicon of the New Testament, vol. 3, Peabody Mass. 1994, 235-239; M. Rosik, Pierwszy List do Koryntian. Wstęp, przekład z oryginału, komentarz, Częstochowa 2009, 500.

${ }^{7}$ Cf. Evangelium Philippi 56, 15 - 57, 8, ed. B. Layton, Nag Hammadi Codex II, 2-7, vol. 1, NHS 20, Leiden 1989, 152-154.
} 
Gnosticism, the Bishop of Lyons devotes much attention to the controversial sentence of St. Paul. He states there emphasising rhetorically:

"[St. Paul's] text is quoted in folly by all heretics to argue on its basis that there is no salvation for the work of God's hands"

"[they] do not comprehend the Apostle's concept [...] holding the literal meaning of the words $[\ldots]$ obliterating the whole plan of God"'.

Previously, in the first book of his work, Irenaeus attacked the Gnostic sect of Ophites that criticised Christians for their contrary to Saint Paul's vision of Christ's return to life in an worldly body (in corpore mundiali resurrexisse) ${ }^{10}$.

The remaining conditioned by anti-Valentinian polemics analysis, to be found in chapters 8-14 of Book V of Adversus haereses, leans towards demonstrating that the phrase "flesh and blood" stands for the sinful deeds of the flesh (acta carnalia) and one's arrogant conduct (pristina vanitatis conversatio) leading to spiritual death, but not the bodily substance (non substantia carnis) or the image of bodily form (imago plasmatis) $)^{11}$. The successive commentaries of the Asian tradition are found to be in a like manner, as for instance the homilies to the First Letter to Corinthians provided by the author of "the Pauline corpus" and the greatest commentator of the patristic period, i.e. John Chrysostom ${ }^{12}$. This approach to interpretation is distinctive - as we shall see - even for the Alexandrian tradition, and occurs as well in Latin exegesis, case in point being Pelagius' commentary to the Letter to the Romans ${ }^{13}$, or commentary by Ambrosiaster to the 1Cor 15:50 verse, where there is a moral justification for body as the attitude of lack of faith (incredulitas, perfidia), and

${ }^{8}$ Irenaeus, Adversus haereses V 9, 1, ed. A. Rousseau - L. Doutreleau - Ch. Mercier, SCh 153, Paris 1969, 106: "Id est quod ab omnibus hereticis profertur in amentia sua, ex quo et ostendere conantur non salvari plasmationem Dei", translated by the author.

${ }^{9}$ Ibidem V 13, 2, SCh 153, 168: "neque sensum Apostoli perspexerunt [...] nude autem ipsas dictiones tenentes [...] universam dispositionem Dei [...] evertentes", translated by the author.

${ }^{10}$ Cf. ibidem I 30, 13, ed. A. Rousseau - L. Doutreleau, SCh 264, Paris 1979, 382.

${ }^{11}$ Cf. ibidem V 14, 1, SCh 153, 182: "Quoniam autem non adversus ipsam substantiam carnis et sanguinis dixit Apostolus non possidere eam regnum Dei”; ibidem V 14, 4, SCh 153, 192: "Si igitur caro et sanguis sunt quae faciunt nobis vitam, non proprie de carne dictum est et sanguine non posse ea possidere regnum Dei, sed de praedictis carnalibus actibus qui, ad peccatum transvertentes hominem, privant eum vita"; ibidem V 11, 2, SCh 153, 138: "Abluti autem sumus non substantiam corporis neque imaginem plasmatis, sed pristinam vanitatis conversationem. In quibus igitur periebamus membris, operantes ea quae sunt corruptelae, in iisdem ipsis vivificamur, operantes ea quae sunt Spiritus". See E. Osborn, Irenaeus of Lyons, Cambridge 2001, 240-241.

${ }^{12}$ Cf. Joannes Chrysostomus, In Epistulam 1 ad Corinthios hom. 42, 1, PG 61, 363-364.

${ }^{13}$ Cf. Pelagius, In Epistulam 1 ad Corinthios Expositio 15, 50, ed. A. Hamman, PLS 1, Paris 1958, 1233: "Frequenter Scriptura carnem pro operibus nominat carnis, ut ibi: <vos autem in carne non estis, sed in spiritu> (Rom 8: 9)". 
the blood as sinful and lavish life (vita turpis et luxuriosa) ${ }^{14}$. Incidentally, this is one of the few extant endeavours to separately deal with flesh and blood, because the majority of authors of the patristic era treat this phrase as hendiadys and focus on the meaning of the term $\sigma \alpha ́ \alpha \xi$.

In Irenaeus' judgment the raison d'être of the physical body is not annihilation, for if the human body (caro) could not be saved, Christ would not incarnate into it descending upon earth ${ }^{15}$. The author of Adversus haereses believes however that the words of St. Paul can be under a certain assumption interpreted literally, associated with the bodily matter. In such wise the perishable physical body itself (caro sola, membra hominis) indeed cannot inherit the Kingdom of God, but must be included into inheriting it by the Spirit (caro a Spiritu possessa) ${ }^{16}$. According to the rhetoric of the Bishop of Lyons man will be resurrected in substance of his body (in carnis substantia), but not by its substance (non ex sua substantia) ${ }^{17}$. In Irenaeus' trichotomous (body - soul - spirit) ${ }^{18}$ anthropology the Holy Spirit is the indispensable complement of human nature and provides man with the likeness of God ${ }^{19}$. The body is an inactive component - being saved and formed (salvatum et formatum), being possessed (possidetur). Whereas the Spirit is an active force that saves and shapes (salvans et figurans), takes into possession (possidet) and transforms; deprives the body not of its substance, but the characteristics of corruptibility and mortality ${ }^{20}$. Thereby, through interpreting the Pauline text in such a manner, Irenaeus refers to the idea attributed by Methodius of Olym-

${ }^{14}$ Cf. Ambrosiaster, Commentarius in 1 Epistulam ad Corinthios, ed. H.J. Vogels, CSEL 81/2, Vindobonae 1968, 183: "Carnem perfidiam vult intellegi, sanguinem autem turpem et luxuriosam vitam, quia cupiditas haec fervore sanguinis generatur, ut ostenderet non solum incredulum dignitosam resurrectionem non habere, verum etiam illum qui desideriis et vitiis carnis obtemperat".

${ }^{15} \mathrm{Cf}$. Irenaeus, Adversus haereses V 14, 1, SCh 153, 182: "si enim non haberet caro salvari, nequaquam Verbum Dei caro factum esset".

${ }^{16}$ Cf. ibidem V 9, 3, SCh 153, 114-116: "Quoniam igitur sine Spiritu Dei salvari non possumus, adhortatur Apostolus nos per fidem et castam conversationem conservare Spiritum Dei [...] et clamavit non posse carnem solam et sanguinem regnum Dei possidere".

${ }^{17}$ Cf. ibidem V 6, 2 - 7, 1, SCh 153, 84: "corpora nostra non ex sua substantia, sed ex Dei virtute suscitantur [...] Christus in carnis substantia surrexit".

${ }^{18}$ Cf. A. Orbe, Antropología de San Ireneo, Madrid 1969; H. de Lubac, Anthropologie tripartite, in: idem, Théologie dans l'histoire, vol. 1: La lumière du Christ, Paris 1990, 115-127; Szram, Ciało zmartwychwstate, p. 217-223.

${ }^{19}$ Cf. Irenaeus, Adversus haereses V 9, 3, SCh 153, 112-114: "caro a Spiritu possessa, oblita quidem sui, qualitatem autem Spiritus assumens, conformis facta Verbo Dei".

${ }^{20}$ Cf. ibidem V 9, 1, SCh 153, 106: "altero quidem salvante et figurante, qui est Spiritus, altero quod salvatur et formatur, quod est caro, altero quod inter haec est duo, quod est anima: quae aliquando quidem subsequens Spiritum, elevatur ab eo; aliquando autem consentiens carni, decidit in terrenas concupiscentias"; ibidem V 9, 4, SCh 153, 118: "caro haec secundum seipsam, id est sola, regnum Dei hereditate possidere non potest, hereditate autem possideri in regno a Spiritu potest". See Y. de Andia, Homo vivens. Incorruptibilité et divinisation de l'homme selon Irénée de Lyon, Paris 1986, 287. 
pus to Saint Justin - namely that the body does not inherit the Kingdom of God, but is inherited, with the difference that the author of Adversus haereses clearly emphasizes the Holy Spirit as the perpetrator of that inheritance ${ }^{21}$.

2. Tertullian - the North African tradition. In the chapters 48-51 of the treaty De resurrectione carnis Tertullian's commentary to Saint Paul's sentence is corresponding to Irenaeus' - it has a polemical stance towards the extremely literal exegesis of this verse by the Gnostics: supporters of Valentinus, Apelles, Basilides and Marcion of Sinope ${ }^{22}$. Despite the fact that in other instances of the treaty the Carthaginian criticises the straying away from the literal understanding of the concept of caro in the resurrective context ${ }^{23}$, but regarding the interpretation of the analysed verse considers the figurative reading sound and in accord with the way of thinking of the Apostle. The body that will not inherit the Kingdom of God is equivalent - as emphasized by Tertullian and Irenaeus - to the conduct of an "old man" (conversatio vetustatis) ${ }^{24}$. The main distinction between the negative in moral understanding of the term caro, and its ontological meaning, morally neutral, can be found in one of Tertullian's comments, put in his favourite form of a paradox:

"No one lives more physically (carnaliter) than those who deny the resurrection of the flesh (caro)" ${ }^{\prime 25}$.

One of the original element of Carthaginian's exegesis is the explanation referring to the purpose, which - according to Saint Paul - cannot be arrived at neither by flesh, nor blood, comprehended as the contamination with sin coetaneous with man's earthly life. Tertullian remarks:

${ }^{21}$ Cf. Methodius Olympius, De resurrectione II 18, 9-11, ed. G. Bonwetsch, GCS 27, Leipzig 1917, 370-371. See P. Prigent, Justin et l'Ancien Testament. L'argumentation scripturaire du traité contre toutes les hérésies comme source principale du Dialogue avec Tryphon et de la première apologie, Paris 1964, 46 and 50; Pietrella, Caro et sanguis, p. 59-60.

${ }^{22}$ Cf. Tertullianus, De praescriptione haereticorum 30, 9-12, ed. R.F. Refoulé, CCL 1, Turnhout 1954, 211; idem, De carne Christi 8, 2, ed. A. Kroymann, CCL 2, Turnhout 1954, 890; idem, De resurrectione carnis 5, 2, ed. J.G.Ph. Borleffs, CCL 2, 926; idem, Adversus Marcionem V 10, 11-15, ed. A. Kroymann, CCL 1, 694-695.

${ }^{23} \mathrm{Cf}$. idem, De resurrectione carnis 23-24 and 28, CCL 2, 949-953 and 957.

${ }^{24}$ Cf. ibidem 49, 7-11, CCL 2, 991-992: "conversatio autem vetustatis non capit Dei regnum, proinde caro et sanguis non capiendo Dei regnum ad conversationem rediguntur vetustatis"; ibidem 46, 9, CCL 2, 984: "non caro adversatur saluti, sed operatio carnis". See J. Alexandre, Une chair pour la gloire. L'anthropologie réaliste et mystique de Tertullien, Théologie historique 115, Paris 2001, 506; Pietrella, Caro et sanguis, p. 66-69.

${ }^{25}$ Tertullianus, De resurrectione carnis 11, 1, CCL 2, 933: "Nemo enim tam carnaliter vivit quam qui negant carnis resurrectionem", translated by the author. 
"It is not hence the resurrection that is directly denied to flesh and blood, but the kingdom of God, which follows the resurrection"26.

Commenting on the similar in content Pauline Letter to Galatians 5:19-21 ("The acts of the flesh are obvious [...] those who live like this will not inherit the kingdom of God") the Carthaginian theologian makes a clear distinction between the bodily resurrection of all people in the ontological order (resurrectio generalis in iudicium) and the resurrection of the selected in the order of salvation (resurrectio specialis in regnum). Both instances of resurrection refer to the body in the ontological meaning, that is referring to the living substance of a man (genus substantiae), which includes physical earthly body. However, the body cannot rise from the dead for the Kingdom in the moral sense, that is the evil deeds committed in earthly life (opus substantiae ${ }^{27}$. In the above-distinction made by Tertullian one discerns a clear polemic with the Valentinians, for whom there is no such instance of resurrection from the dead in an ontological, "neutral" and designed for all people, but resurrection is solely saving, applies only to particular and is spiritual ${ }^{28}$.

What is more, Tertullian also allows for a materialistic understanding of the Pauline phrase "flesh and blood will not inherit the Kingdom". According to the Carthaginian the body - despite the possibility of being resurrected in the earthly form - cannot enter into such a state to the Kingdom of God. It must first go through a transition and clothe itself in the appropriate quality of indestructibility and immortality, while maintaining its bodily substance ${ }^{29}$. Such an interpretation may be found among Irenaeus' writings and was idiosyncratic with the majority of the early Christian exegetes from different traditions. One can discern it in the fourth and fifth centuries: in the commentary on the First Letter to the Corinthians provided by the representative of the Asian tradition, Theodoret of $\mathrm{Cyrus}^{30}$; as well as in the preserved fragments of its commentary

${ }^{26}$ Ibidem 50, 2, CCL 2, 992: "Non enim resurrectio carni et sanguini directo negatur, sed Dei regnum, quod obvenit resurrectioni", translated by the author.

${ }^{27}$ Cf. ibidem 50,2-3, CCL 2, 992: "est autem et in iudicium resurrectio - immo et confirmatur carnis resurrectio generalis, cum specialis excipitur. Dum enim in quem statum non resurgat edicitur, in quem resurgat subauditur. Atque ita, dum pro meritis distinctionem resurrectionis opus substantiae non genus, patitur, apparet hinc quoque carnem et sanguinem nomine culpae, non substantiae, arceri a Dei regno, nomine tamen formae resurgere in iudicium, quia non resurgant in regnum".

${ }^{28}$ Cf. Pietrella, Caro et sanguis, p. 70-71.

${ }^{29}$ Cf. Tertullianus, De resurrectione carnis 50, 4-6, CCL 2, 992-993: "Merito ergo caro et sanguis, ut diximus, sola regnum Dei capere deficiunt. Iam vero, cum devorari habeat corruptivum istud $\mathrm{ab}$ incorrutibilitate, id est caro, et mortale istud ab inmortalitate (cf. 1Cor 15:53-54), id est sanguis, post resurrectionem ex demutatione, merito demutata ac devorata caro et sanguis regnum Dei hereditati possidere possunt non tamen non resuscitata".

${ }^{30}$ Cf. Theodoretus Cyrensis, Commentarius in Epistulam 1 ad Corinthios 15, 50, PG 82,

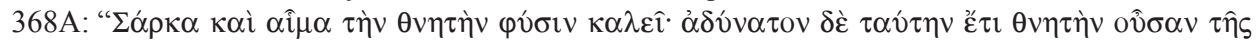


by a representative of the Alexandrian tradition, Cyril ${ }^{31}$; additionally, in the writings of the Latin exegetes: Ambrose, Ambrosiaster and Augustine in the late period of his creativity ${ }^{32}$.

Tertullian referring to Saint John's words "It is the spirit that gives life; the flesh is useless" (Jn 6:63) also emphasizes, as does Irenaeus, that the bodily elements of the structure of the human person cannot by themselves return to life and enter into the Kingdom of God. The resurrection of a body requires the power of God working through the Spirit, whereas the entrance into the Kingdom is allowed only through deeds done in the Spirit ${ }^{33}$.

The provided by Irenaeus and Tertullian exegesis of Paul's verse proved to share many features. At present, one should consider on how does it diverge from an interpretation by a representative of the Alexandrian tradition, i.e. Origen.

3. Origen - the Alexandrian tradition. Origen, threading upon on the subject of spiritual warfare of a spiritual inner man with his carnal external counterpart in his writings emphasised that the commonly negatively understood carnality concerns the sphere of the lust or acts made upon and in the body - not the body itself as a particular material substance ${ }^{34}$. Such an approach facilitated his spiritual interpretation of the Pauline verse. In his Homi-

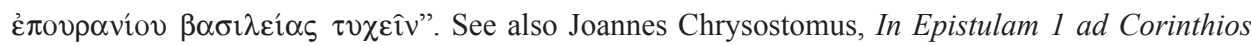
hom. 42, 2, PG 61, 364-365.

${ }^{31} \mathrm{Cf}$. Cyrillus Alexandrinus, Explanatio in Epistulam 1 ad Corinthios, PG 74, 912B: " $\Sigma v v i ́ \sigma \tau \eta \sigma \mathrm{v}$

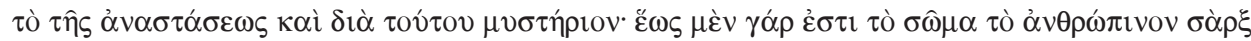

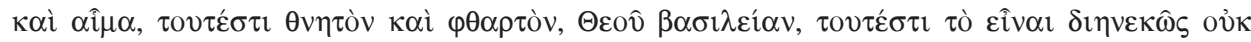

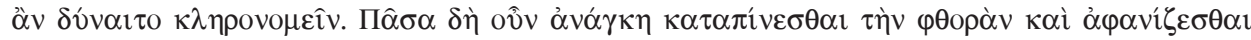

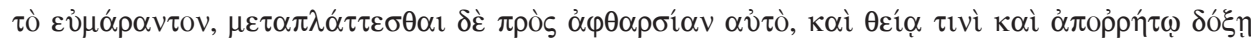

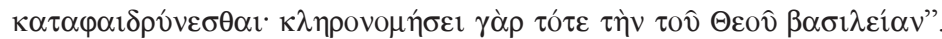

${ }^{32}$ Cf. Ambrosius, Exameron V 23, 78, ed. C. Schenk1, CSEL 32/1, Pragae - Vindobonae - Lipsiae 1897, 196; Augustinus, De civitate Dei 13, 20, ed. B. Dombart - A. Kalb, CCL 48, Turnhout 1955, 403: "Sicut enim spiritus carni serviens non incongrue carnalis, ita caro spiritui serviens recte appellabitur spiritalis, non quia in spiritum convertetur, sicut nonnulli putant ex eo quod scriptum est: $<$ Seminatur corpus animale, surget corpus spiritale $>$, sed quia spiritui summa et mirabili obtemperandi facilitate subdetur usque ad implendam immortalitatis indissolubilis securissimam voluntatem, omni molestiae sensu, omni corruptibilitate et tarditate detracta"; idem, Epistula 205, 15-16, ed. A. Goldbacher, CSEL 57, Vindobonae - Lipsiae 1911, 336-337: "Caro et sanguis regnum Dei non possidebunt, quia non ibi erit corruptio et mortalitas carnis et sanguinis; secundum has enim qualitates hoc loco carnem et sanguinem nuncupavit".

${ }^{33}$ Cf. Tertullianus, De resurrectione carnis 50, 4-6, CCL 2, 992-993: "Adhuc dicam: Caro et sanguis regnum Dei hereditati possidere non possunt (1Cor 15:50), merito sola et per semetipsa, ut ostenderet adhuc spiritum in illis necessarium. Spiritus enim est qui vivificat in regnum Dei, caro nihil prodest (Jn 6, 63). Prodesse tamen illi aliud potest, id est spiritus, et per spiritum opera quoque spiritus". See F. Altermath, Du corps psychique au corps spirituel. Interprétation de 1 Cor. 15, 35-49 par les auteurs chrétiens des quatre premiers siècles, Tübingen 1977, 132-134.

${ }^{34}$ Cf. Origenes, Commentarii in Iohannem XIII 42, 280, ed. C. Blanc, SCh 222, Paris 1975, 181-182. See H. Crouzel, Origène, Paris 1985, 126-130. 
lies on the Psalms, preserved in a Jerome's Latin translation, Origen says similarly to the Asian and North African tradition representatives - that those who will be resurrected in imitation of Christ, will have flesh (caro), but will not worship the matters of the flesh (carnis opera) ${ }^{35}$. This interpretation was firmly rooted in the Alexandrian tradition, found for example in Clement's of Alexandria Stromata ${ }^{36}$.

However, among the writings of Origen one may find also statements showing he recognizes the words of Saint Paul very literally and - in contrast to Irenaeus and Tertullian - seems to question the possibility of resurrection of a body built of earthly matter. The Alexandrian states in the apology Contra Celsum:

"We do not preach [...] that God raises the dead flesh and blood"37;

"According to God's will the divine quality that the matter presently has, will be later on unlike, let's say frankly, improved and more faultless" ${ }^{\prime 38}$.

Elsewhere in the same work the Alexandrian suggests that the human soul in a new environment does not need terrestrial body. Referring to the Pauline image - "What you sow, you do not sow the body that is to be, but a bare seed, perhaps of wheat or of some other grain" (cf. 1Cor 15:35-38) - illustrates the view that another body dies, and yet another - better and more perfect - arises from the dead ${ }^{39}$. Moreover, it's not just about deprivation of the characteristics of corruptibility and mortality, as Irenaeus and Tertullian believed. The background polemics with Celsus, accusing Christians of believing in the return of rotten flesh to life, indicates that in Origen's notion of an earthly material body, termed $\sigma \alpha ́ \rho \xi$, should be replaced after the instance of resurrection with an ethereal counterpart, adapted to the new conditions ${ }^{40}$. According to a concept

${ }^{35}$ Cf. Origenes - Hieronymus, Tractatus sive homiliae in Psalmos 143, 3, ed. G. Morin, CCL 78, Turnholti 1958, 314.

${ }^{36}$ Cf. Clemens Alexandrinus, Stromata II 125, 6, ed. C. Mondesert - P.Th. Camelot, SCh 38, Paris 1954, 127.

${ }^{37}$ Origenes, Contra Celsum VI 29, ed. M. Borret, SCh 147, Paris 1969, 252: "'A $\lambda \lambda$ ' o 0 '

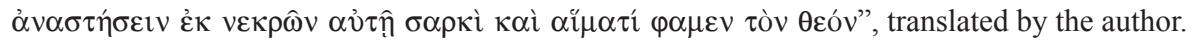

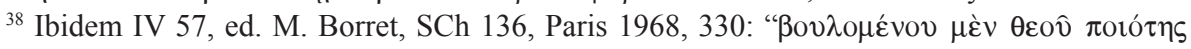

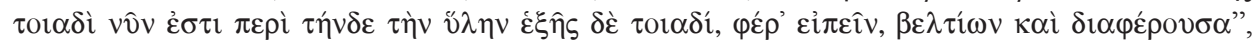
translated by the author.

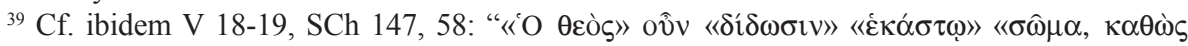

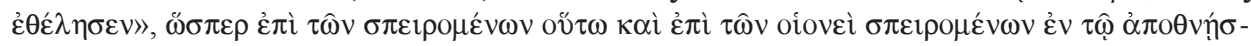

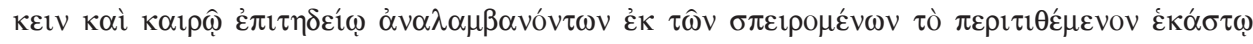

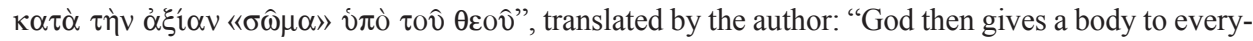
one, the already sown seeds, as well as those that are as if sewn onto death, only to receive of the sewn bodies at the appropriate time such a one God sees fit for their merits".

${ }^{40}$ Cf. idem, De principiis I 6, 4, ed. H. Crouzel - M. Simonetti, SCh 252, Paris 1978, 206: "Alius fortasse dicet quoniam in illo fine omnis substantia corporalis ita pura erit atque purgata, ut aetheris in modum et caelestis cuiusdam puritatis ac sinceritatis possit intellegi"; idem, Stromata 
put forward in Origen's missing passage from a commentary on Psalm 1 quoted at the beginning of the fourth century by Methodius of Olympus in the treatise On the Resurrection - the resurrected body would be linked with the earthly body not through the same substrate material, but more or less an unspecified related to the matter, a fixed form of bodily identity, denoted by a Platonic-Aristotelian term عî̀os - "idea", "principle", the "essence of things" ${ }^{41}$. In contrast, a naturalistic understanding of the resurrected body as identical with the earthly one is attributed by Origen to the ordinary people, abecedarian in faith ${ }^{42}$.

Despite the fact that in a few passages of the extant commentaries on the First Letter to Corinthians Origen claims that the dead should be resurrected in a like body as Christ, who has been seen eating, however he uses a broader meaning to the term $\sigma \hat{\omega} \mu \alpha$, and not $\sigma \alpha{ }^{\rho} \xi^{43}$. One must also remember that in the cited by Jerome portion of the lost works of Origen, Stromata, the Alexandrian

(fragmenta), in: Hieronymus, Liber ad Pammachium contra Iohannem Hierosolymitanum 26, 5457, ed. J.-L. Feiertag, CCL 79A, Turnhout 1999, 46: "Aliud [corpus] nobis spiritale et aetherium promittitur, quod [...] pro locorum, in quibus futurum est, varietate mutabitur". See A. Vitores, Identidad entre el cuerpo muerto e resuscitado en Origenes segun el De resurrectione de Metodio di Olimpo, Studium Biblicum Franciscanum, Analecta 18, Jerusalem 1981, 233-236; M. Mees, Paulus, Origenes und Methodius über die Auferstehung der Toten, “Augustinianum” 26 (1986) 109-110; Szram, Ciało zmartwychwstate, p. 594-605.

${ }^{41}$ Cf. Origenes, Commentarii in Psalmos (fragmenta) 1, 5, in: Methodius, De resurrectione

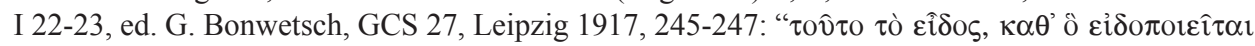

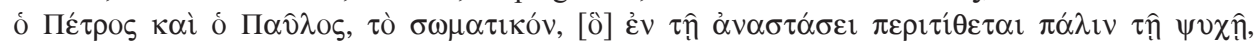

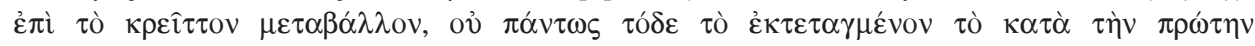

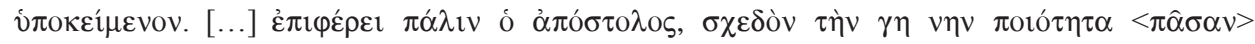

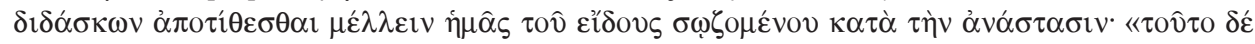

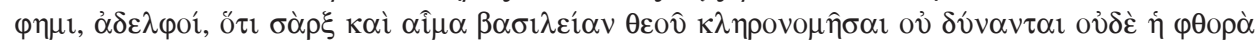

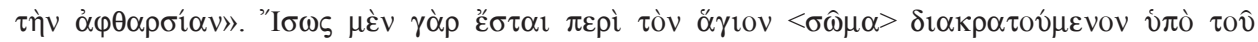

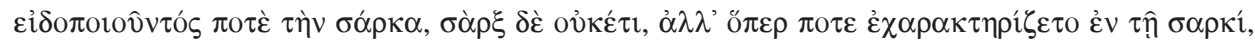

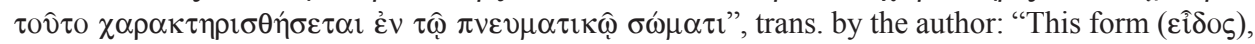
according to which were shaped Paul and Peter, will once more be put onto a soul when resurrection

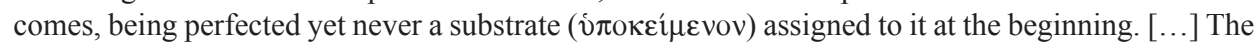
Apostle while instructing that during the raising from the dead we will have to remove probably the entire earthly quality of us, teaches that our form will remain intact, adding that: «What I am saying, brothers and sisters, is this: flesh and blood cannot inherit the kingdom of God, nor does the perishable inherit the imperishable» (1Cor 15:50). The saint's body $(\sigma \hat{\omega} \mu \alpha)$ will have been retained by He, who has shaped it, yet the earthly body ( $\sigma \alpha ́ \rho \xi)$ will be no more, leaving its characteristic features ( $\sigma \alpha \dot{\alpha} \rho \xi)$ to be present in the spiritual body ( $\dot{\varepsilon} \nu \tau \hat{\omega} \pi \nu \varepsilon v \mu \alpha \tau \imath \kappa \hat{\omega} \sigma \omega \dot{\varphi} \mu \alpha \tau \imath)$ ".

${ }^{42}$ Cf. idem, Contra Celsum V 18, SCh 147, 56; idem, De principiis III 6, 5, ed. H. Crouzel M. Simonetti, SCh 268, Paris 1980, 246.

${ }^{43}$ Cf. idem, Fragmenta Commentariorum in Epistulam 1 ad Corinthios 84, ed. C. Jenkins,

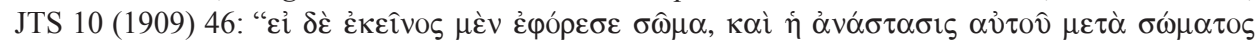
ทิv author: "If Christ had the flesh $(\sigma \hat{\omega} \mu \alpha)$, His resurrection was corporeal, for He has been eating as is written in the Gospel of John". 
states that Jesus by eating, drinking and allowing to be touched after his returning from the dead has adjusted to the Apostles' perception, to arouse their faith in the reality of resurrection. Although, simultaneously his body had air and spiritual qualities to it, which manifested itself in passing through closed doors, appearing and disappearing ${ }^{44}$. On the other hand, in Contra Celsum he adds that after the transition period between the resurrection and ascension, when Jesus has been appearing to his disciples "as if on the border between the heaviness of the body, which was before the Passion, and the state in which the soul appears liberated from this body"45, Christ's human body by the

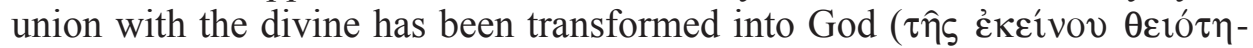

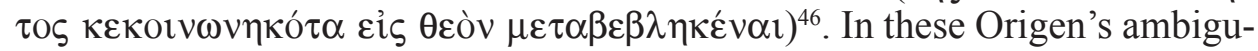
ous statements, characteristic for his hypothetical and exploratory manner of practicing theology, one can discern a departure from the common to all the early Christian traditions reading of the St. Paul's text, that gave it moral and spiritual import. Even if it allowed for a literal meaning, it did not lead towards undermining the possibility of resurrection of an earthly body ${ }^{47}$. Origen, by the means of his interpretation, more or less consciously, leaned towards the direction of the Gnostics, who consented to the resurrection of the spiritual body, completely different in terms of the substantial structure from its carnival counterpart, or some individual body of the soul, as evidenced by the gnostic statements contained in Tertullian's apology Adversus Marcionem ${ }^{48}$. Incidentally, a similar reasoning just post to his conversion (before 396) had St. Augustine, who - probably under the influence of Manichaeism - did not distinguish caro as a carnival matter from caro as the physical characteristics of the body and was convinced that the earthly caro will be after the resurrection transformed into a new kind of body - corpus ${ }^{49}$.

${ }^{44}$ Cf. idem, Stromata (fragmenta), in: Hieronymus, Liber ad Pammachium contra Iohannem Hierosolymitanum 26, 64-73, CCL 79A, 47: “Comedit post resurrectionem suam et bibit, vestitus apparuit, tangendum se praebuit, ut dubitantibus apostolis fidem faceret resurrectionis. Sed tamen non dissimulat naturam aerii corporis et spiritalis. Clausis enim ingreditur ostiis, et in fractione panis ex oculis evanescit".

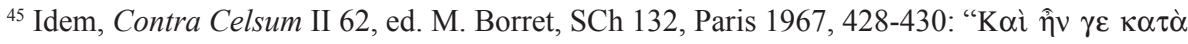

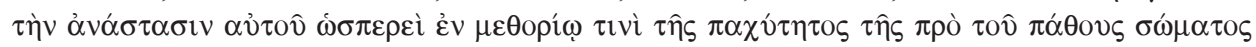

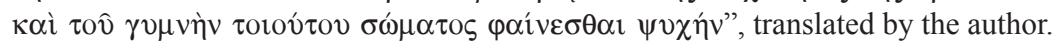

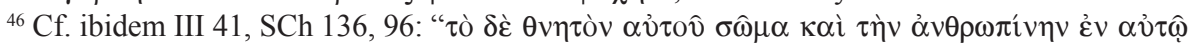

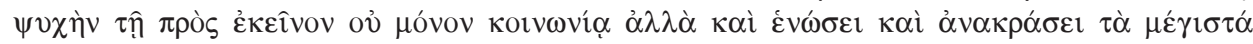

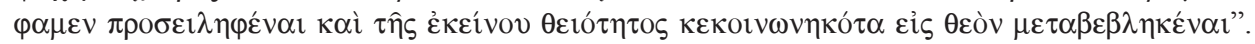

${ }^{47}$ Cf. E. Prinzivalli, Magister Ecclesiae. Il dibattito su Origene fra III e IV secolo, SEA 82,

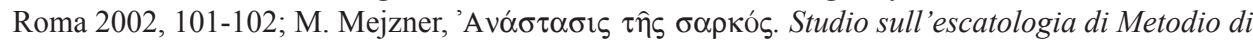
Olimpo (Excerpta ex dissertatione ad Doctoratum in Theologia et Scientiis Patristicis), Roma 2007, 43-44; idem, L'escatologia di Metodio di Olimpo, SEA 124, Roma 2011, 309.

${ }^{48}$ Cf. Tertullianus, Adversus Marcionem V 10, 3. 6, CCL 1, 692-693.

${ }^{49} \mathrm{Cf}$. Augustinus, De agone cristiano 32, 34, PL 40, 309: "Immutabitur ergo caro et sanguis, et fiet corpus coeleste et angelicum"; idem, De fide et symbolo 10, 23-24, PL 40, 195: "illo tempore 
The main conclusion of the presented analysis corresponds with the thesis of M. Simonetti, outlined in his classic monograph on the history of patristic exegesis Lettera elo allegoria. Un contributo alla storia dell'esegesi patristica ${ }^{50}$ : although the Asian and North African traditions were associated more with literal exegesis, and Alexandrian with the allegorical one, there has been no instance of mutual exclusion of the two methods of interpretation, but rather their interpenetration. The analysed comments concerning the Pauline verse have shown that sometimes even a paradoxical situation occurred when the follower of literal reading or moderate allegorising Tertullian attached more importance to the figurative meaning of the text than the declared follower of allegorising Origen, who in turn opted for its far-reaching verbatim interpretation. The reasons for such an attitude could be twofold. On the one hand, the theological orientation of exegesis entailing involvement in the doctrinal disputes of that times, in this case dealing with the Gnostics, determined the method of interpretation. On the other hand, the early Christian authors attempted to support a specific method of exegesis to present their own original solutions in philosophy and theology (as was in the case of Origen's concept of resurrection solely of the form of earthly body - $\varepsilon \hat{i} \delta o \varsigma$, without its material content $-\sigma \alpha ́ \rho \xi)$. Such conduct - for which the Gnostics were stigmatized by Origen, despite he himself also employed it but to a much lesser extent could give rise to reasonable suspicion of over-interpreting the inspired text, which Methodius of Olympus pitted against Origen in the controverting with the Alexandrian notions of resurrection treatise De resurrectione.

Translated by Michał Matusiak

\section{JAKIE CIAŁO NIE ODZIEDZICZY KRÓLESTWA BOŻEGO? WCZESNOCHRZEŚCIJAŃSKA EGZEGEZA 1KOR 15, 50}

\section{(Streszczenie)}

Celem artykułu jest prześledzenie egzegezy wersetu 1Kor 15, $50 \mathrm{w}$ literaturze wczesnochrześcijańskiej na przykładzie pism trzech autorów, reprezentujących

\footnotetext{
immutationis angelicae non iam caro erit et sanguis, sed tantum corpus. [...] in coelestibus vero nulla caro, sed corpora simplicia et lucida, quae appellat Apostolus spiritualia, nonnulli autem vocant aetherea"; idem, Contra Adimantum Manichaei discipulum 12, PL 42, 146: "Hinc ergo adparet, quia caro et sanguis regnum Dei non possidebunt, quia cum induerit incorruptionem et immortalitatem, iam non caro et sanguis erit, sed in corpus caeleste mutabitur". See P.J. Fletcher, Resurrection Realism. Ratzinger the Augustinian, Eugene 2014, 43-46.
}

${ }^{50}$ Roma 1985. 
podstawowe tradycje geograficzno-kulturowe funkcjonujące w Kościele pierwszych wieków: Ireneusza z Lyonu - przedstawiciela tradycji azjatyckiej; Tertuliana z Kartaginy - związanego z tradycją północnoafrykańską, zbliżoną w wielu punktach do azjatyckiej; oraz Orygenesa - wywodzącego się z tradycji aleksandryjskiej. U wszystkich wspomnianych pisarzy przeważała interpretacja moralna zwrotu „ciało i krew” jako grzesznych uczynków, które należy porzucić, aby wejść do królestwa niebieskiego. Każdy z nich dopuszczał jednak również swoistą interpretację dosłowną tego wersetu, próbując pogodzić ją $\mathrm{z}$ fundamentalną prawdą wiary o cielesnym zmartwychwstaniu: Ireneusz akcentował, że ciało nie może zmartwychwstać i osiagnąć królestwa Bożego o własnych siłach, a jedynie z pomocą Ducha Świętego; Tertulian był przekonany, że ciało w ziemskiej postaci zmartwychwstanie, ale nie będzie mogło wejść do królestwa niebieskiego bez przyjęcia nowych cech; Orygenes posunął się najdalej, podając w wątpliwość powrót do życia ciał w ziemskim kształcie. Przeanalizowane komentarze do Pawłowego wersetu dowodza, że egzegeza patrystyczna była ukierunkowana teologicznie i zależna od ówczesnych sporów doktrynalnych. Ukazują też pewien paradoks: niekiedy w celu uzasadnienia konkretnego stanowiska filozoficzno-teologicznego zwolennik literalizmu lub umiarkowanej alegorezy mógł przywiązywać większą wagę do przenośnego znaczenia tekstu natchnionego niż zdeklarowany alegorysta, który z kolei odwoływał się do daleko idącej interpretacji dosłownej.

Key words: body, resurrection, St. Paul, patristic exegesis, Irenaeus, Tertullian, Origen.

Słowa kluczowe: ciało, zmartwychwstanie, św. Paweł, egzegeza patrystyczna, Ireneusz, Tertulian, Orygenes.

\section{BIBLIOGRAPHY}

\section{Sources}

Ambrosiaster, Commentarius in 1 Epistulam ad Corinthios, ed. H.J. Vogels, CSEL 81/2, Vindobonae 1968, 3-194.

Ambrosius, Exameron, ed. C. Schenkl, CSEL 32/1, Pragae - Vindobonae - Lipsiae 1897, 3-261.

Augustinus, Contra Adimantum Manichaei discipulum, PL 42, 129-172.

Augustinus, De agone cristiano, PL 40, 289-310.

Augustinus, De civitate Dei, ed. B. Dombart - A. Kalb, CCL 47-48, Turnholti 1955.

Augustinus, De fide et symbolo, PL 40, 181-196.

Augustinus, Epistulae, ed. A. Goldbacher, vol. 4, CSEL 57, Vindobonae - Lipsiae 1911.

Clemens Alexandrinus, Stromata, II, ed. C. Mondesert - P.Th. Camelot, SCh 38, Paris 1954.

Cyrillus Alexandrinus, Explanatio in Epistulam 1 ad Corinthios, PG 74, 856-916.

Evangelium Philippi, ed. B. Layton, Nag Hammadi Codex II, 2-7, vol. 1, NHS 20, Leiden 1989, 142-215.

Joannes Chrysostomus, In Epistulam 1 ad Corinthios homiliae, PG 61, 9-382. 
Irenaeus, Adversus haereses, ed. A. Rousseau - L. Doutreleau - B. Hemmerdinger Ch. Mercier, I, SCh 263-264, Paris 1979; II, SCh 293-294, Paris 1982; III, SCh 210 211, Paris 1974; IV, SCh 100/1-2, Paris 1965; V, SCh 152-153, Paris 1969.

Methodius Olympius, De resurrectione, ed. G. Bonwetsch, GCS 27, Leipzig 1917, 217-424.

Origenes - Hieronymus, Tractatus sive homiliae in psalmos, ed. G. Morin, CCL 78, Turnholti 1958, 1-447.

Origenes, Commentarii in Iohannem, ed. C. Blanc, I-V, SCh 120, Paris 1966; VI, X, SCh 157, Paris 1970; XIII, SCh 222, Paris 1975; XIX-XX, SCh 290, Paris 1982; XXVIIIXXXII, SCh 385, Paris 1992.

Origenes, Contra Celsum, ed. M. Borret, I-II, SCh 132, Paris 1967; III-IV, SCh 136, Paris 1968; V-VI, SCh 147, Paris 1969; VII-VIII, SCh 150, Paris 1969; Introduction et index, SCh 227, Paris 1976.

Origenes, De principiis, ed. H. Crouzel - M. Simonetti, I-II, SCh 252-253, Paris 1978; III-IV, SCh 268-269, Paris 1980; Compléments et index, SCh 312, Paris 1984.

Origenes, Fragmenta Commentariorum in 1 Epistulam ad Corinthios, ed. C. Jenkins, JTS 9 (1908) 231-247, 353-372 and 500-514; JTS 10 (1909) 29-51.

Origenes, Commentarii in Psalmos (fragmenta), in: Methodius Olympius, De resurrectione I 22-23, ed. G. Bonwetsch, GCS 27, Leipzig 1917, 242-250.

Origenes, Stromata (fragmenta), in: Hieronymus, Liber ad Pammachium contra Iohannem Hierosolymitanum Episcopum et Rufinum Origenis Adsertorem, ed. J.-L. Feiertag, CCL 79A, Turnholti 1999, 40-48.

Pelagius, In Epistulam 1 ad Corinthios Expositio, ed. A. Hamman, PLS 1, Paris 1958, 1181-1236.

Tertullianus, Adversus Marcionem, ed. A. Kroymann, CCL 1, Turnholti 1954, 441-726.

Tertullianus, De carne Christi, ed. A. Kroymann, CCL 2, Turnholti 1954, 871-917.

Tertullianus, De praescriptione haereticorum, ed. R.F. Refoulé, CCL 1, Turnholti 1954, 185-224.

Tertullianus, De resurrectione carnis, ed. J.G.P. Borleffs, CCL 2, Turnholti 1954, 919-1012.

Theodoretus Cyrensis, Commentarius in Epistulam 1 ad Corinthios, PG 82, 225-376.

\section{Literature}

AleXANDRE J., Une chair pour la gloire. L'anthropologie réaliste et mystique de Tertullien, Théologie historique 115, Paris 2001.

Altermath F., Du corps psychique au corps spirituel. Interprétation de 1 Cor. 15, 35-49 par les auteurs chrétiens des quatre premiers siècles, Tübingen 1977.

BARrett C.K., A Commentary on the First Epistle to the Corinthians, London 1968.

Boucaud P., Corpus Paulinum. L'exégèse grecque et latine des Épitres au premier millénaire, RHR 230 (2013) fasc. 3, 299-332.

Crouzel H., Origène, Paris 1985.

De Andia Y., Homo vivens. Incorruptibilité et divinisation de l'homme selon Irénée de Lyon, Paris 1986. Fletcher P.J., Resurrection Realism. Ratzinger the Augustinian, Eugene 2014.

Gundry R.H., $\Sigma \hat{\omega} \mu \alpha$ in Biblical Theology with Emphasis on Pauline Anthropology, Cambridge 1976.

JewetT R., Paul's Anthropological Terms. A Study of Their Use in Conflict Settings, Leiden 1971. 
Kovacs J.L., 1 Corinthians Interpreted by Early Christian Commentators, Grand Rapids 2005.

LÉOn-Dufour X., Ciało, in: Słownik teologii biblijnej, translated from French to Polish:

K. Romaniuk, Poznań - Warszawa 1985, 140-146.

Mees M., Paulus, Origenes und Methodius über die Auferstehung der Toten, "Augustinianum" 26 (1986) 103-113.

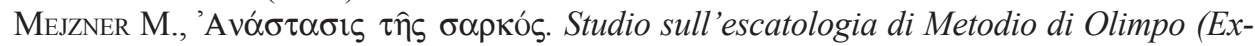
cerpta ex dissertatione ad Doctoratum in Theologia et Scientiis Patristicis), Roma 2007.

Mejzner M., L'escatologia di Metodio di Olimpo, SEA 124, Roma 2011.

Orbe A., Antropología de San Ireneo, Madrid 1969.

Osborn E., Irenaeus of Lyons, Cambridge 2001.

Pietrella E., "Caro et sanguis regnum Dei possidere non possunt" (1 Co XV, 50), "Aevum" 49 (1975) 36-76.

Prigent P., Justin et l'Ancien Testament. L'argumentation scripturaire du traité contre toutes les hérésies comme source principale du Dialogue avec Tryphon et de la première apologie, Paris 1964.

Prinzivalli E., Magister Ecclesiae. Il dibattito su Origene fra III e IV secolo, SEA 82, Roma 2002.

Robinson J.A.T., The Body: A Study in Pauline Theology, London 1952.

Rosik M., Pierwszy List do Koryntian. Wstęp, przekład z oryginatu, komentarz, Częstochowa 2009.

SAND A., Der Begriff "Fleisch" in den paulinischen Hauptbriefen, Regensburg 1967.

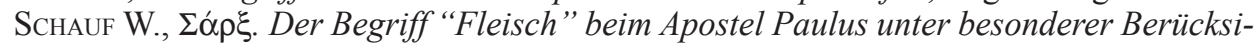
chtigung seiner Erlösungslehre, Münster 1924.

Simonetti M., Asiatica (cultura), DPAC I 414-416.

SimonetTi M., Lettera e/o allegoria. Un contributo alla storia dell'esegesi patristica, SEA 23, Roma 1985.

SimonetTi M., Modelli culturali nella cristianità orientale del II-III secolo, in: De Tertullien aux Mosarabes. Antiquité tardive et Christianisme ancien (III ${ }^{e}-V I^{e}$ siècles). Mélanges offerts à Jacques Fontaine, ed. L. Holtz - J.C. Fredouille - M.H. Jullien, vol. 1, Paris 1992, 381-392.

Simonetti M., Teologia alessandrina e teologia asiatica al concilio di Nicea, "Augustinianum" 13 (1973) 369-398.

SpicQ C., Theological Lexicon of the New Testament, vol. 3, Peabody Mass. 1994.

Szram M., Ciało zmartwychwstałe w myśli patrystycznej przełomu II i III wieku, Lublin 2010.

The New International Dictionary of New Testament Theology, ed. C. Brown, vol. 1-3, Exeter - Devon - Grand Rapids - Michigan 1975-1978.

Vitores A., Identidad entre el cuerpo muerto e resuscitado en Origenes segun el De resurrectione de Metodio di Olimpo, Studium Biblicum Franciscanum, Analecta 18, Jerusalem 1981. 